\title{
Freshwater Scarcity and Sustainable Water Management in the Hindu Kush-Himalayan (HKH) Region
}

\author{
Pabitra Gurung and Tashi Yang Chung Sherpa
}

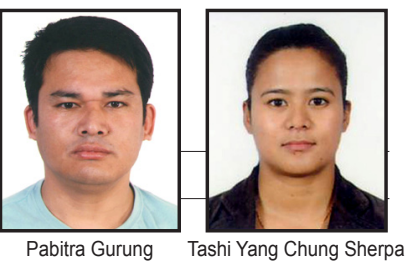

Abstract: Water is essential for every life on the earth and for many forms of socioeconomic development activity. Freshwater scarcity is a major issue in the developing world in terms of human consumption and irrigation. Water is not evenly distributed therefore some regions (particularly in South Asia and Africa) will experience intensified water scarcity in coming years. The stressors on water are population growth and climate change. These stressors are exacerbated by poor management and policy on the part of ruling governments. Climate change is of keen interest as it will impact water availability in unpredictable ways. In this context, it is essential to develop efficient adaptive tactics (e.g., water storage) to anticipate these changes. The paper, then, will look into the global scenario of water demand, as well as examine regional conflicts that may become worse under the stress of water scarcity.

Key words: Water scarcity, water demand and supply, water management, watershed interventions, HKH region

\section{Introduction}

Tot only is water essential for human life, but also for all forms of socioeconomic development. Nearly $70 \%$ of the earth is covered with water and this contains approximately 1.4 billion cubic kilometers of water. Only 2.5\% of the global water is fresh water and the remaining $97.5 \%$ is salt water (figure 1). The largest amount of usable water is stored in underground aquifers and the remainder is stored in the atmosphere, natural lakes, reservoirs, and rivers. Among the available freshwater, $69 \%$ of the water is in the form of snow and glaciers, while $30.7 \%$ is stored in the underground, and remaining $0.3 \%$ is in the lakes and rivers (FAO 2009). This means that less than $1 \%$ of total freshwater is available for human and ecosystem use (WBCSD 2005).

Figure 2 represents the per capita annual water available in the world. Based on the UN Medium Population Projections, more than 2.8 billion people in 48 countries will face water scarcity by 2025 and 40 of these countries are in the West Asia, North Africa or sub-Saharan Africa (Nellemann and Kaltenborn 2009). If the population growth remains same then water scarce countries will rise to 54 by 2025. This will affect approximately 4 billion people living

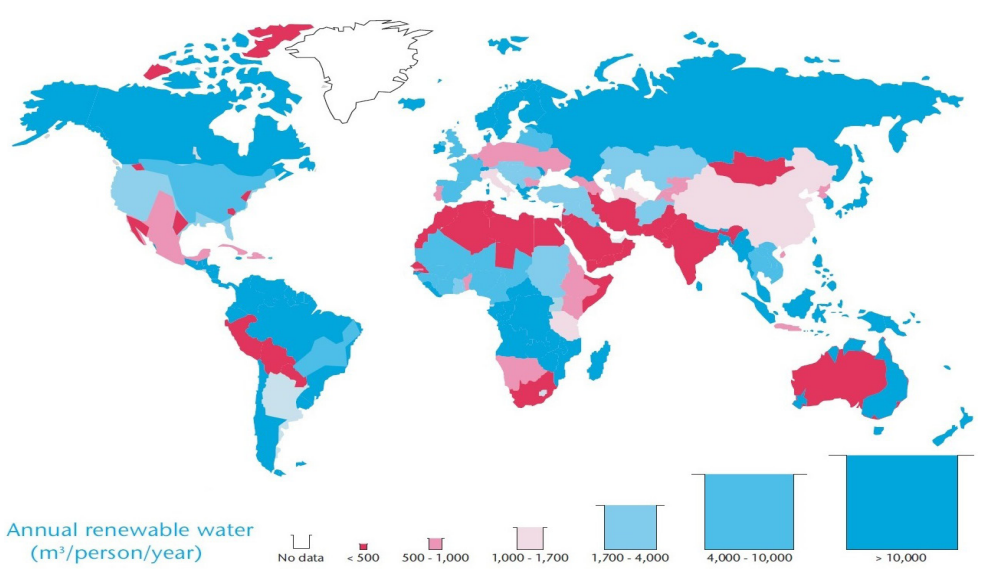

Figure 2: Annual renewable water available in the world (WBCSD, 2005; Revenga, 2001) in those countries which will be almost $40 \%$ people of the world population (Nellemann and Kaltenborn, 2009). In 1950, the global population was roughly 2.5 billion and today that number has risen to 7 billion (Mc Cornick et al. 2013). Today, 500 million people are subject to water scarcity and that figure will increase to approximately 3 billion by 2025 while the global population overall is projected to reach about 9.6 billion by 2050 (Hanjra and Qureshi 2010; Mc Cornick et al. 2013). This population increase will trigger intense food demands which will

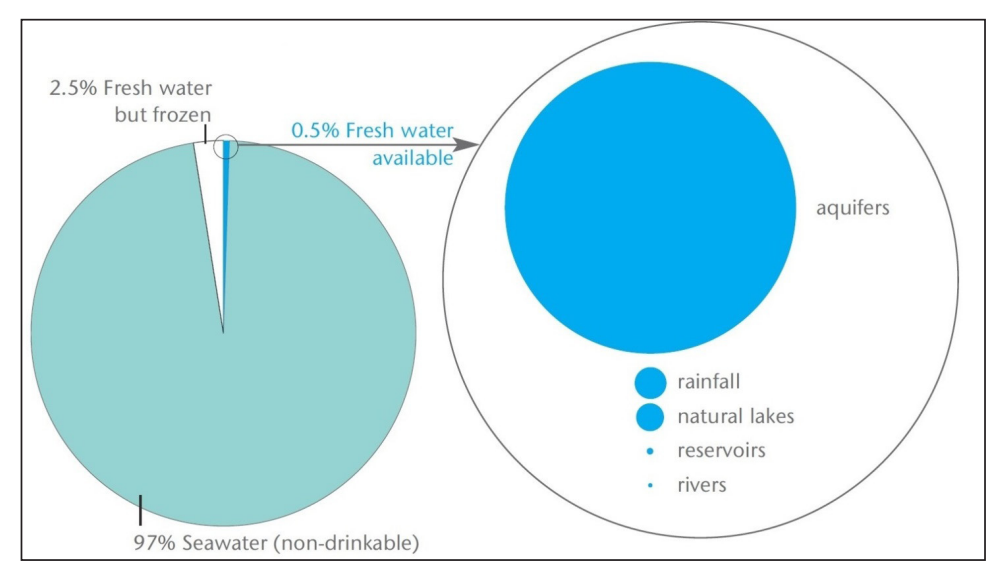

Figure 1: Freshwater available on the earth (FAO, 2009; WBCSD, 2005) ultimately influence land and water resources management (Mc Cornick et al. 2013).

Figure 3 illustrates projected water scarcity in 2025. This water scarcity map has been prepared based on food production needs to meet the demands of increasing population (Rijsberman 2006). Almost all the developing countries from South America, Africa and Asia, including Australia will suffer from water scarcity in 2025 while North America, Europe and Northern Asia will face few water scarcity problems. Physical water scarcity leads to problems such as environmental degradation and ground water depletion (Molden 2007). 

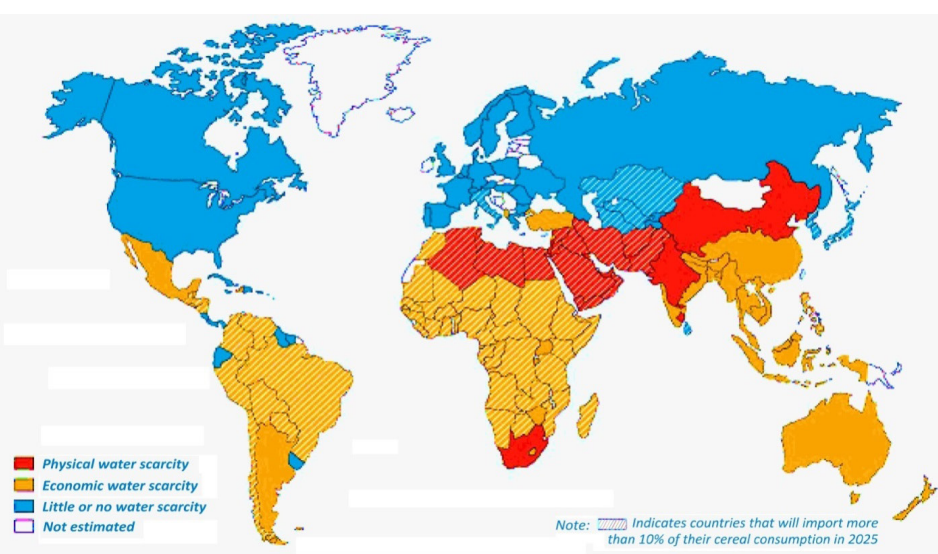

Figure 3: Projected Global Water Scarcity in 2025 (IWMI, 2000; Rijsberman, 2006)

In the Himalayan region, most of the human settlements and agricultural lands are on the top lap of the hills and along the ridges while the streams/rivers run down in the valley. Therefore, huge investment will be required to provide water to the people living in the high hills.

In general, water is needed to fulfill domestic, irrigation, and industrial demands (Sapkota et al. 2013). A large amount of water is needed for cultivation to meet food demands (Seckler et al.1998) and for industry to process products (Kemp et al., 2010). Globally, water use for domestic, irrigation and industry approach 10\%, 70\% and $20 \%$, respectively, of the total water withdrawn from surface water and ground water (Wisser et al. 2008). Additionally, sufficient freshwater is needed to maintain answers to the following sets of questions for the Hindu Kush-Himalayan (HKH) region of Asia.

a) How will the water crisis impact natural systems?

b) Should water scarcity be a debate for academic and policy sectors?

c) Does water scarcity really exist or is it fiction?

d) What are water demand and supply scenarios?

e) What is the relationship between water and poverty?

f) Who owns the water and who is responsible to manage it for sustainable development?

\section{The Hindu Kush-Himalayan (HKH) Region}

The mountainous territories of the HKH range (figure 4) extend from Myanmar in the east to Afghanistan in the west running about 2,400 kilometers in length. The Himalayas sare the source of water for ten major Asian rivers, including Amu Darya, Tarim, Indus, Ganges, Brahmaputra, Irrawaddy, Salween, Mekong, Yangtze and Yellow river (ICIMOD 2011). Together, these rivers occupy about 8.6 million square kilometers of area and run through 16 different countries of Asia: Uzbekistan, Turkmenistan, Tajikistan, Kyrgyzstan, Afghanistan, Pakistan, India, Nepal, Bangladesh, Bhutan, Myanmar, China, Laos, Thailand, Cambodia, and Vietnam. For this reason, the Himalayan region is often called the "water tower of the Asia". The HKH region (which has freshwater-based ecosystems (Petrov et al. 1993) and cultural/religious water requirements, such as river water needed for Hindu rites (Alley 2002; Duncan 1950). Climate change and excessive withdrawal of water are major factors that affect freshwater availability. Thus the world's water demand is increasing rapidly along with increasing demand from industries and population, but the supply of the water is declining, especially in the developing countries (Gleick, 2003; Seckler et al., 1998). The problem of water scarcity has increased disputes among the water users and raised many questions about water rights. In a lesser developed country like Nepal, one of the persisting challenge to water scarcity is unequal

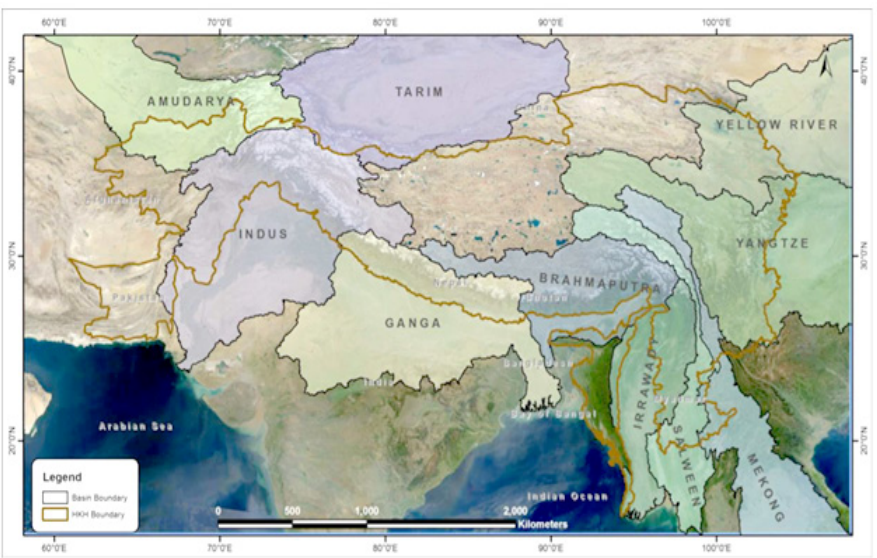
land ownership structure and class inequalities (Sugden et al. 2013, 2014). Disputes on the issues of water rights, requirements, and water use are becoming more critical due to increasing demands for economic development, a better environment, health and hygiene, and societal and cultural values.

The purpose of this paper is to project and analyze the consequences of regional water scarcity and the efforts of local level water management. By reviewing and synthesizing the literature, we attempt to outline the global water demand and supply scenario, regional conflict and water scarcity, and the best water management options for local levels by exploring the

an area about 3.44 square kilometers) covers parts of Afghanistan, Pakistan, India, China, Bangladesh and Myanmar, and all of Nepal and Bhutan. The Himalayan region has the largest ice coverage outside the polar caps with more than 100,000 square kilometers (Vaidya 2009); and the glaciated area is 33,000 square kilometers (Hua 2009). Hence, the rivers of HKH region are dominated by glacier and snow melt.

\section{Water Scarcity in the HKH Region}

The great mountains in the $\mathrm{HKH}$ region are the primary water source for a large number of people living in Asia. Approximately $70 \%$ to $90 \%$ of the freshwater of the $\mathrm{HKH}$ 
region is used to irrigate agricultural lands (Nellemann and Kaltenborn 2009). However, the region is also facing a water crisis problem, and according to the projections, water stress will grow in the future (IWMI 2000). Major causes for water scarcity in these regions are population growth, food production, and climate change (Rijsberman 2006). Nearly 100,000 children are born every day and the population will grow to 8 billion by 2050 (Nellemann and Kaltenborn 2009). At present, about $10 \%$ to $25 \%$ of the freshwater is used for households but this will increase in future due to population growth; and we need more water to produce more food to feed animals and for human consumption. Additional 30\% to 50\% water will be required in a next few decades in the agricultural sector and will rise from $70 \%$ to $80 \%$ by 2050 (Nellemann and Kaltenborn 2009). Additionally, climate change has altered the seasonal variability in the flow of Asian rivers (Bharati et al. 2011; 2012). This reduces water availability during dry seasons in the regions where water flows consistently decrease on the snow and glacier fed rivers.

Cereal production and cereal demand is increasing in the HKH region. Water from the Himalayas and the central Asian mountain support the cereal production over 500 million tons every year (Nellemann and Kaltenborn 2009). This is $55 \%$ of cereal production in all of Asia and $25 \%$ of the world. Rice is a staple crop for people living in $\mathrm{HKH}$, even though rice is a particularly water-intensive crop. In addition, meat consumption rates are increasing in this region. Studies show that compared to water required for grains, meat requires ten times more water to produce a kilogram (Rijsberman 2006). As a result of these many factors, for first time in the human history, water consumption and freshwater pollution will reach levels where water scarcity may limit food production, urban water supply, and ecosystem function in coming decades (Jury and Vaux 2007).

\section{Impacts of Water Scarcity in the HKH Region Water supply and sanitation}

Water is crucial to health and hygiene in every community. However, despite recent huge investments in water and sanitation of the region, a large number of people still do not have basic water and sanitation services (Wijesekera 2006). In terms of health and hygiene, developing countries are more vulnerable due to poverty and have more restricted access to water resources. The population growth in the developing countries and increasing water demand has severely affected water supply so as to maintain improved sanitation practices. Therefore, the water scarcity increases threat of the epidemic water borne diseases, particularly in poor communities, which, in turn, influences infant and child mortality rates. Nearly half the people in developing countries suffer from diseases caused by insufficient and poor water supply and sanitation (WHO 2004).

\section{Environment and ecology}

Environmental degradation is one of the serious problems of the $\mathrm{HKH}$ region due to climate change, water overuse, and poorly-managed urbanization. Landslides and floods are common natural disasters in the HKH region (Shrestha 2007). They sweep away fertile soil and affect the sub-surface hydro geological condition of the region (ICSU 2008). Changes in subsurface hydrological conditions is one reason why spring sources in the hills and mountains dry up, thus depriving hill residents of sources for drinking water (HELVETAS 2013).The temperature of the region is also increasing as a consequence of the global warming (Hua, 2009). This brings various problems such as faster snow and glacier retreat in the region; shifting up agro-ecological zone, and land degradation. Therefore, water scarcity is changing the hydrology and ecology of the watersheds which ultimately impacts the environment and water resources of the region.

\section{Agricultural production}

The concept of 'green revolution' was introduced during 1960 s to save millions of people from starvation by producing a high variety of food grains using hybrid seeds, fertilizers and pesticides; and by applying sufficient water through modern irrigation technology (Hazell 2009). Due to changing irrigation technology, farmers want to grow high value crops to earn more profit (Gleick 2003). Therefore, farmers' interest in cash crops and the concept of efficient water use is also changing water demand. However, decreases in water availability will seriously impact food production and Asian cereal productions will draw down by $10 \%$ to $30 \%$ more than projected for future (Nellemann and Kaltenborn 2009). Lack of access to markets, high prices for fertilizer and seeds, lack of infrastructure and investment, and unreliable institutions are also major challenges in the agricultural sector (Sugden et al. 2013; 2014).

\section{Livelihoods and socioeconomic}

In the future, the price of water will increase due to water scarcity. This will hike the prices of commodities and food as well. Moreover, there will be a reduction in food production due to less available water while, on the other hand, food demand will increase to meet an increasing population. Based on projections from the World Bank (WB), FAO, and United Nations (UN) reports, food prices will increase by $30 \%$ to $50 \%$ in the future (Nellemann and Kaltenborn 2009). This will escalate poverty in the developing countries where poor people are spending $70 \%$ to $80 \%$ of their income on food. Therefore, the least developed countries will be more vulnerable in terms of suffering an environmental food crisis (Nellemann and Kaltenborn 2009).

\section{Water Resources and Management Water resources and climate change}

Major rivers of the world draw their water from glaciers and snowmelt. Due to global warming, 
temperatures are rising and glacier retreat and snowmelt processes are increasing in pace (Pelto 2013). More specifically, temperatures are increasing by $0.03{ }^{\circ} \mathrm{C}$ per year in the $\mathrm{HKH}$ region and even higher in the mountain region when compared to lowlands (Hua 2009; Rangwala and Miller 2012). Changes in monsoon patterns and rising temperature have contributed to the depletion of the glaciated area in the $\mathrm{HKH}$ region and this ultimately is impacting river basin hydrology (Nellemann and Kaltenborn 2009). Therefore, people of developing countries are more vulnerable due to their limited capacity to adapt (Siddiqui et al. 2012). As a result, both flood and drought are increasing by intensity and timing while agro ecological zones are shifting.

\section{Water management in local context}

\section{River basin development}

River basin development planning is necessary to conserve water for the future. And knowledge of the hydrological processes in the basin is required to overcome water scarcity problems and improve water allocation practices. However, river basin development will depend on the understanding of local residents and local bodies, and the policies of government (Mc Cormick et al. 2013; Sugden et al. 2013, 2014). Therefore, the idea of storing excess water to use in water scarce periods to increase crop productivity has been pitched as the "Blue revolution" (Mac Cartney and Smakhtin 2010).

Water storage will be effective option to better manage water to fulfill demand in an era of climate change (Hua 2009; Mac Cartney and Smakhtin 2010). A critical challenge in developing countries is how to deal with the increased variability and uncertainty of rainfall pattern that affect farming systems of the region (Sugden et al. 2013,2014 ). Changes in rainfall will impact variability of ground water recharge and river flow. Therefore, water storage will be the best option to elevate water security, agricultural production, and adaptive capacity to climate change if it is planned and managed properly. However, water storage must be complemented with other practices (Mac Cartney and Smakhtin 2010; Vaidya 2009).

\section{Watershed vulnerability}

As part of river basin development, studies have shown that the vulnerability assessments of watersheds need to be completed prior to any basin level planning (Siddiqui et al. 2012). The vulnerability ranking is most important in developing countries where investment is limited. Watershed level management schemes can be started in the most vulnerable watershed as a pilot project. Then the outcomes of those projects can be used in the development of other watershed plans. In the context of Nepal, socioeconomic and physical parameters are considered to prepare watershed vulnerability maps. The vulnerability assessment is carried out in three levels: sensitivity analysis, adaptive capacity analysis, and exposure/risk analysis (Siddiqui et al. 2012). Combining the results of these three assessments renders a final vulnerability ranking.

\section{Watershed interventions}

The major challenge of the $\mathrm{HKH}$ region is too much water in monsoon and too little water in winter. As a solution, excess water from monsoon needs to be stored for times of drought. Countries like Nepal have focused only on land degradation management so far as watershed interventions are concerned, and this practice is not enough to address the issues of livelihood and environment (CGIAR 2013). Therefore, based on the studies and practices around the world (Garg et al. 2012; Singh et al. 2013), watershed technologies such as storage ponds, infiltration ponds, terracing farm lands, and a forestation need to be considered for implementation.

\section{Payment for Ecosystem Services (PES)}

Payment for Ecosystem Services (PES) is essential for the sustainable conservation of water resources, sustainable land management, and minimizing environmental degradation (UNECE 2007). The idea of PES has been developed as a win-win for both conservation and development objectives (Mc Elwee 2012; Schomers and Matzdorf 2013). Infrastructure across rivers will affect the function of river water ecosystems, and it has to pay high economic and environmental costs (Fu et al. 2014). PES will provide incentives and benefits for people who wish to protect their ecosystem services for the wider communities (Karky and Joshi 2009) and assist in sustainable watershed development (Khanal and Paudel 2012).

\section{Conclusions}

If we consider global water availability and demand, we can see that the real problem is water management. However, freshwater distribution is not even throughout the world and this creates challenges to water allocation and management as required. For example, countries like Canada have surplus freshwater, but this surplus water cannot be used for the deficit areas of the world. We understand the principles of inter basin water transfer but this can only be done regionally. Therefore, regional level management plans and policies are essential for proper management of water resources to increase food production and watershed development.

The idea behind watershed interventions is to preserve excess water during high precipitation periods or events (e.g. monsoon) to use for irrigation during periods of low precipitation and high demand. The water can be stored either in surface or in the sub-surface by natural or artificial infrastructures. However, focus should be on small scale watershed interventions and to improve irrigation systems (Sugden et al. 2013, 2014). The amount of irrigation water must be based on the requirement of crop characteristics. That is how we can increase crop water productivity. In addition, we need to identify alternative sources of cereal to feed animals and this will help to reduce water consumption. We also need to promote small scale farming business to adapt impact of the climate change and need to promote eco-based 
farming system to reduce the spread of invasive species, and to maintain sound bio-diversity and ecosystem. PES is one of the best option to manage water without environmental degradation and for the sustainable development of the water resources (Mc Elwee 2012). However, population growth control and development of adaptive capacity to climate change is essential for the future water security. Therefore, regional scale integrated water policy is needed for the sustainable development and management of the water resources.

\section{Acknowledgements}

First of all we are thankful to Prof. Dr. Stephen Déry, Prof. Dr. Neil Hanlon, and Prof. Dr. Bill McGill of University of Northern British Columbia (UNBC) for their valuable supports and suggestions which really helped us to enhance our knowledge in the interdisciplinary sectors. In addition, we would like to thank all the proofreaders; Dr. Kalsang Norbu Gurung, Ms. Bunu Gauli Sharma, and Mr. Aseem Sharma; for their valuable time to go through the manuscript and provide their valuable comments to improve the language of this manuscript.

Pabitra Gurung, PhD Student, the University of Northern British Columbia, Prince George, Canada. $M r$. Gurung has over nine years working experience in the field of water resources. He has a Bachelor degree in civil engineering from Tribhuvan University, Nepal and a Master Degree in Water Resources Engineering degree from Katholieke Universiteit Leuven, Belgium. He has worked in projects in Nepal, India and Belgium, particularly in the field of watershed development. His key area of interest and expertise are: hydrological analysis and modelling, crop water modelling, hydraulic design and climate change impact studies on water resources.

Corresponding address: Pabitra.gurung@gmail.com

Tashi Yang Chung Sherpa, MA, Independent Consultant. Ms. Sherpa has over five years working experience in the field of social sciences, particularly focusing on the issues of water resources development. She has a Bachelor of Arts degree in Rural Development from Purbanchal University, Nepal and a Master's Degree in Rural Development from Tribhuvan University, Nepal. She has worked in many projects in Nepal and she is still working in the field of both research and development. Her key area of interest and expertise are: social survey and analysis, policy analysis, sustainable development, particularly focusing on the issues of water security.

Email:taseedele@hotmail.com

\section{References}

Alley, K.D., 2002. On the Banks of the Gagā: When Wastewater Meets a Sacred River. University of Michigan Press, Michigan, USA.

Bharati, L., P. Gurung, and P. Jayakody, 2012. Hydrologic
Characterization of the Koshi Basin and the Impact of Climate Change. Hydro Nepal: Journal of Water, Energy and Environment:18-22.

Bharati, L., G. Lacombe, P. Gurung, P. Jayakody, C.T. Hoanh, and V. Smakhtin, 2011. The Impacts of Water Infrastructure and Climate Change on the Hydrology of the Upper Ganges River Basin. IWMI Research Report 142. Colombo, Sri Lanka: International Water Management Institute.

Bogardi, J.J., D. Dudgeon, R. Lawford, E. Flinkerbusch, A. Meyn, C. Pahl-Wostl, K. Vielhauer, and C. Vörösmarty, 2012. Water Security for a Planet under Pressure: Interconnected Challenges of a Changing World Call for Sustainable Solutions. Environmental Sustainability 4:35-43.

CGIAR, 2013. Re-Thinking Investment: Watershed Management in Nepal. Washington, D.C., USA: Consultative Group of International Agriculture Research.

Duncan, D.D., 1950. A Million Hindus Wash Away Their Sins. LIFE 18:25 - 29.

FAO, 2003. Water Reports 23: Review of World Water Resources by Country. Rome, Italy: Food and Agriculture Organization of the United Nations.

FAO, 2009. Water Scarcity: Some Quick Facts about Water. Food and Agriculture Organization of the United Nations. http://www.youtube.com/watch?v=XGgYTcPzexE (Accessed on November 15, 2013).

Fu, B., Y.K. Wang, P. Xu, K. Yan, and M. Li, 2014. Value of Ecosystem Hydropower Service and Its Impact on the Payment for Ecosystem Services. Science of The Total Environment 472:338-346.

Garg, K.K., L. Karlberg, J. Barron, S.P. Wani, and J. Rockström, 2012. Assessing Impacts of Agricultural Water Interventions in the Kothapally Watershed, Southern India. Hydrological Processes. doi:http:// dx.doi.org/10.1002/hyp.8138.

Gleick, P.H., 2003. Global Freshwater Resources: Soft-Path Solutions for the 21st Century. Science 302:1524-1528.

Hanjra, M.A. and M.E. Qureshi, 2010. Global Water Crisis and Future Food Security in an Era of Climate Change. Food Policy 35:365-377.

Hazell, P.B.R., 2009. The Asian Green Revolution. Discussion Paper. International Food Policy Research Institute, Washington, DC, USA.

HELVETAS, 2013. Water Resources Management Programme. HELVETAS Swiss Intercooperation Nepal. http://nepal.helvetas.org/en/our_projects/ warm.cfm. Accessed 10 Dec 2013.

Hua, O., 2009. The Himalayas - Water Storage under Threat. Water Storage: A Strategy for Climate Change Adaptation in the Himalayas. Sustainable Mountain Development. ICIMOD 56:3-5.

ICIMOD, 2011. From Rio 1992 to 2012 and beyond: Sustainable Mountain Development Hindu Kush Himalaya (HKH) Region, Regional Assessment Report for Rio+20: Hindu Kush Himalaya and SE Asia Pacific Mountains. Kathmandu, Nepal: International Centre for Integrated Mountain Development.

ICSU, 2008. Science Plan on Hazards and Disasters: Earthquakes, Floods and Landslides. Kaula Lumpur, Malaysia: International Council for Science. 
IWMI, 2000. World Water Supply and Demand in 2025. In Rijsberman, F.R. (Ed.). World Water Scenario Analyses. World Water Council, Marseille, France.

Jury, W.A. and H.J. Vaux, 2007. The Emerging Global Water Crisis: Managing Scarcity and Conflict Between Water Users. Advances in Agronomy 95:1-76.

Karky, B.S. and L. Joshi, 2009. Payment for Environmental Services - an Approach to Enhancing Water Storage Capacity. Water Storage: A Strategy for Climate Change Adaptation in the Himalayas. Sustainable Mountain Development. ICIMOD 56:31-33.

Kemp, D., C.J. Bond, D.M. Franks, and C. Cote, 2010. Mining, Water and Human Rights: Making the Connection. Journal of Cleaner Production 18:1553-1562.

Khanal, R. and D. Paudel, 2012. Payment for Ecosystem Services (PES) Schemes for Conserving Sardu Watershed Nepal: Existing Practices and Future Prospects. Kathmandu: IUCN Nepal.

MacCartney, M. and V. Smakhtin, 2010. Water Storage in an Era of Climate Change: Addressing the Challenge of Increasing Rainfall Variability. Colombo, Sri Lanka: International Water Management Institute.

McCornick, P., V. Smakhtin, L. Bharati, R. Johnston, M. McCartney, F. Sugden, F. Clement, and B. Mclntyre, 2013. Tackling Change: Future-Proofing Water, Agriculture, and Food Security in an Era of Climate Uncertainty. Colombo, Sri Lanka: International Water Management Institute.

McElwee, P.D., 2012. Payments for Environmental Services as Neoliberal Market-Based Forest Conservation in Vietnam: Panacea or Problem? Geoforum 43:412-426.

Molden, D., 2007. A Comprehensive Assessment of Water Management in Agriculture. Colombo, Sri Lanka: International Water Management Institute.

Nellemann, C. and B.P. Kaltenborn, 2009. The Environmental Food Crisis in Asia - a "Blue Revolution" in Water Efficiency Is Needed to Adapt to Asia's Looming Water Crisis. Ater Storage: A Strategy for Climate Change Adaptation in the Himalayas. Sustainable Mountain Development. ICIMOD 56:6-9.

OECD, 2005. Issues Brief: Water and Violent Conflict. Paris, France.

Pelto, M.S., 2013. Global Glacier Retreat. North Cascade Glacier Climate Project, Nichols College, Dudley, Massachusetts, USA. http://www.nichols.edu/ departments/glacier/glacier_retreat.htm. Accessed 10 Dec 2013.

Petrov, B. V., E.K. Sinichenko, and E.K. Rabkova, 1993. Effect of Engineering and Economic Activities on Ecological Conditions in River Basins. Hydrotechnical Construction 27:182-184.

Rahaman, M.M., 2009. Integrated Ganges Basin Management: Conflict and Hope for Regional Development. Water Policy 11:168-190.

Rangwala, I. and J.R. Miller, 2012. Climate Change in Mountains: A Review of Elevation-Dependent Warming and Its Possible Causes. Climatic Change 114:527-547.

Revenga, C., 2001. "Will There Be Enough Water?” Earth Trends: $1-5$.

Rijsberman, F.R., 2006. Water Scarcity: Fact or Fiction? Agricultural Water Management 80:5-22.
Sapkota, P., L. Bharati, P. Gurung, N. Kaushal, and V. Smakhtin, 2013. Environmentally Sustainable Management of Water Demands under Changing Climate Conditions in the Upper Ganges Basin, India. Hydrological Processes 27:2197-2208.

Schomers, S. and B. Matzdorf, 2013. Payments for Ecosystem Services: A Review and Comparison of Developing and Industrialized Countries. Ecosystem Services:e1-e15.

Seckler, D., U.A. Amarasinghe, D. Molden, R. de Silva, and R. Barkar, 1998. World Water Demand and Supply 1990 to 2025: Scenarios and Issues. Research Report 19. Colombo, Sri Lanka: International Water Management Institute.

Shrestha, A.B., 2007. Flash Floods in the Himalayas. Kathmandu, Nepal: International Centre for Integrated Mountain Development.

Siddiqui, S., L. Bharati, M. Panta, P. Gurung, B. Rakhal, and L.D. Maharjan, 2012. Climate Change and Vulnerability Mapping in Watersheds in Middle and High Mountains of Nepal. Kathmandu, Nepal: Asian Development Bank.

Singh, R., K.K. Garg, S.P. Wani, R.K. Tewari, and S.K. Dhyani, 2013. Impact of Water Management Interventions on Hydrology and Ecosystem Services in Garhkundar-Dabar Watershed of Bundelkhand Region, Central India. Journal of Hydrology. doi:http://dx.doi.org/10.1016/j.jhydrol.2013.11.030.

Sugden, F., L. Shrestha, L. Bharati, P. Gurung, L. Maharjan, J. Janmaat, J. Price, and T. Sherpa, 2013. Field Report on Small Scale Agricultural Water Storage in Nepal. Kathmandu, Nepal: International Water Management Institute.

Sugden, F., L. Shrestha, L. Bharati, P. Gurung, L. Maharjan, J. Janmaat, J. Price, T. Sherpa, and U. Bhattarai, 2014. Climate Change, out-Migration and Agrarian Stress: The Potential for up-Scaling Small Scale Water Storage in Nepal. IWMI Research Report (In Press). Colombo, Sri Lanka: International Water Management Institute.

UNECE, 2007. Recommendations on Payments for Ecosystem Services in Integrated Water Resources Management. Geneva, Switzerland: Water Convention secretariate, United Nations Economic Commission for Europe.

Vaidya, R.A., 2009. The Role of Water Storage in Adaptation to Climate Change in the HKH Region. Water Storage: A Strategy for Climate Change Adaptation in the Himalayas. Sustainable Mountain Development. ICIMOD 56:10-13.

WBCSD, 2005. Water Facts and Trends. Geneva, Switzerland: World Business Council for Sustainable Development.

WHO, 2004. Facts and Figures: Water, Sanitation and Hygiene Links to Health. World Health Organization.

Wijesekera, N.T.S., 2006. Integrated Urban Water Information Management. Regional Centre on Urban Water Management (RCUWM), UNESCO, Tehran.

Wisser, D., S. Frolking, E.M. Douglas, B.M. Fekete, C.J. Vörösmarty, and A.H. Schumann, 2008. Global Irrigation Water Demand: Variability and Uncertainties Arising from Agricultural and Climate Data Sets. Geophysical Research Letters 35:L24408.

Worldometers, Water Consumption Statistics. http:// www.worldometers.info/water/. Accessed 19 Jun 2014. 